\section{Inhalt}

\section{Anorganische Chemie/Inorganic Chemistry}

Schmidbaur, H., Bublak, W., Schier, A., Reber, G., Müller, G.

Roesky, H. W., Zimmer, M., Noltemeyer, M., Sheldrick, G. M

Köster, R., Seidel, G., Müller, G., Bocse, R. Wrackmeyer, B.

Jutzi, P., Meyer, M.

Jutzi, P., Kroos, R.

Roesky, H. W., Meller, B., Noltemeyer, M., Schmidt, H.-G., Scholz, U., Sheldrick, G. M.

Wiberg, N., Preiner, G. Schurz, K.

Lentz, D., Michael, H.

Wanjek, H., Steimann, M., Beck, W.

Lindner, E., Stängle, M., Hiller, W., Fawzi, R.

Pohlmann, H., Weiss, E.

Hartwig, U., Pritzkow, H., Sundermeyer, W.

Schmidbaur, H., Bach, I., Wilkinson, D. L., Müller, G.

Lentz, D., Graske, K., Preugschat, D.

Ebner, M., Werner, H.

Kerschl, S., Wrackmeyer, B.
1373 cis-1,2-Diphenylcyclopropan: Molekülstruktur und Versuche zur Chelat-Koordination von Gallium(I)

1377 Darstellung von S,S-Diphenyl- $N$-(trimethylsilyl)sulfimin und Reaktionen mit Wolframhexafluorid - Einkristall-Röntgenstrukturanalyse von $\mathrm{F}_{4} \mathrm{~W}\left(\mathrm{~N}=\mathrm{SPh}_{2}\right)_{2}$

1381 Organosubstituierte 2,5-Dihydro-1,2,5phosphasilaborole - Herstellung, Charakterisierung und Umwandlungen

1393 Hochsubstituierte 1-tert-Butyl-1-silacyclohexadiene

1399 Pentamethylcyclopentadienyl-substituierte Cyclophosphane als Quelle für $\mathrm{P}_{\mathrm{x}^{-}}$Einheiten in Übergangsmetallkomplexen

1403 Benzamidinatokomplexe mit Haupt- und Nebengruppen-Elementen - Strukturen von $\mathrm{PhC}\left(\mathrm{NSiMe}_{3}\right)_{2} \mathrm{TiCl}_{2}$ und $\mathrm{PhC}$ $\left(\mathrm{NSiMe}_{3}\right)_{2} \mathrm{MoO}$

1407 Zur Frage der intermediären Bildung von Silanonen $\mathrm{R}_{2} \mathrm{Si}=\mathrm{O}$ bei Reaktionen von $\mathrm{Si}-$ lenen mit Distickstoffoxid

1413 Kopplung eines Fluormethyliden-Liganden mit Alkinen unter Bildung eines $\mathrm{CF}-$ $\mathrm{CR}-\mathrm{CR}$-Liganden. Synthese von $\mathrm{Fe}_{3^{-}}$ $(\mathrm{CO})_{8}\left(\mu_{3}-\mathrm{CF}\right)\left(\mu_{3}-\mathrm{CF}-\mathrm{CR}-\mathrm{CR}\right)$

1417 Metallkomplexe mit biologisch wichtigen Liganden, XLVI. - Platin(II)-Komplexe mit Vorstufen von ungesättigten $\alpha$-Aminosäuren

1421 Darstellung und Eigenschaften von und Reaktionen mit metallhaltigen Heterocyclen, LX. - Untersuchungen zur Darstellung und Struktur von Phosphidomolybdaten

$1427 \mathrm{GeH}_{3}$-substituierte Carbonylmetallate und Carbonyl(cyclopentadienyl)metallate mit $\mathrm{V}, \mathrm{Nb}, \mathrm{Cr}, \mathrm{Mo}, \mathrm{W}, \mathrm{Re}, \mathrm{Co}$ und Ni. - Präparative und röntgenographische Untersuchungen

1435 Aminstabilisierte Sulfene, ihre Darstellung und Struktur

1441 Zink(II)-bis-L-pyroglutamat durch Cyclisierung von L-Glutaminsäure in Gegenwart von Zinkoxid

1445 Synthese von Pentafluorphenylisocyanid und dessen Stabilisierung am Komplex, $\mathrm{Cp} * \mathrm{Mn}(\mathrm{CO})_{2}\left(\mathrm{CN}-\mathrm{C}_{6} \mathrm{~F}_{5}\right)$

Komplexe mit Kohlenstoffsulfiden und -seleniden als Liganden, XXIII. - Synthese von $\mathrm{Pt}(\mathrm{CS})\left(\mathrm{PPh}_{3}\right)_{2}$ und $\mathrm{Pt}(\mathrm{CE})$ $(\mathrm{dpmb})(\mathrm{E}=\mathrm{S}, \mathrm{Se})$ : Die ersten mononuclearen Thio- und Selenocarbonyl-Komplexe von Platin(0)

1451 Synthese von tricyclischen 2,3-Dihydro1H-1,3-stannaborolen

- Publikationssprache

\section{Contents}

cis-1,2-Diphenylcyclopropane: Molecular Structure and Attempted Chelate Complexation of Gallium(I)

Preparation of $S . S$-Diphenyl- $N$-(trimethylsilyl)sulfimine and Reactions with Tungsten Hexafluoride - X-Ray Structure Analysis of $\mathrm{F}_{4} \mathrm{~W}\left(\mathrm{~N}=\mathrm{SPh}_{2}\right)_{2}$

Organosubstituted 2,5-Dihydro-1,2,5phosphasilaboroles - Prcparation, Characterization, and Transformation

Highly Substituted 1-tert-Butyl-1-silacyclohexadienes

Pentamethylcyclopentadienyl-Substituted Cyclophosphanes as a Source for $\mathrm{P}_{\mathrm{x}}$ Units in Transition-Metal Complexes

Benzamidinato Complexes of Main Group and Transition Metals - Crystal Structures of $\mathrm{PhC}\left(\mathrm{NSiMe}_{3}\right)_{2} \mathrm{TiCl}_{2}$ and $\mathrm{PhC}$ $\left(\mathrm{NSiMe}_{3}\right)_{2} \mathrm{MoO}_{2}$

On the Problem of the Intermediate Formation of Silanone $\mathrm{R}_{2} \mathrm{Si}=\mathrm{O}$ by Reactions of Silenes with Dinitrogen Oxide

Coupling of a Fluoromethylidyne Ligand with Alkynes and Formation of a CF$\mathrm{CR}-\mathrm{CR}$ Ligand. Synthesis of $\mathrm{Fe}_{3}(\mathrm{CO})_{8^{-}}$ $\left(\mu_{3}-\mathrm{CF}\right)\left(\mu_{3}-\mathrm{CF}-\mathrm{CR}-\mathrm{CR}\right)$

Metal Complexes of Biologically Important Ligands, XLVI. - Platinum(II) Complexes with Precursors of Unsaturated $\alpha$ Amino Acids

Preparation and Properties of, and Reactions with Metal-Containing Heterocycles, LX. - Investigations on the Preparation and Structure of Phosphidomolybdates

$\mathrm{GeH}_{3}$-Substituted Carbonyl Metallates and Carbonyl(cyclopentadienyl) Metallates with $\mathrm{V}, \mathrm{Nb}, \mathrm{Cr}, \mathrm{Mo}, \mathrm{W}, \mathrm{Re}, \mathrm{Co}$, and Ni. - Preparative and X-Ray Investigations

Amine-Stabilized Sulfenes, their Synthesis and Structure

Zinc(II) Bis-L-pyroglutamate through $\mathrm{Cy}$ clization of L-Glutamic Acid in the Presence of Zinc Oxide

Synthesis of Pentafluorophenyl Isocyanide and Its Stabilization as a Ligand in $\mathrm{Cp} * \mathrm{Mn}(\mathrm{CO})_{2}\left(\mathrm{CN}-\mathrm{C}_{6} \mathrm{~F}_{5}\right)$

Complexes with Carbon Sulfides and Selenides as Ligands, XXIII. - Synthesis of $\mathrm{Pt}(\mathrm{CS})\left(\mathrm{PPh}_{3}\right)_{2}$ and $\mathrm{Pt}(\mathrm{CE})(\mathrm{dpmb})(\mathrm{E}=\mathrm{S}$, $\mathrm{Se})$ : The First Mononuclear Thio- and Selenocarbonyl Complexes of Platinum(0)

Synthesis of Tricyclic 2,3-Dihydro-1 $H$-1,3stannaboroles

- Language of Publication 


\section{Inhalt (Fortsetzung)}

Binger. P., Biedenbach, B., Mynott, R., Regitz, M.

Synthese von Bis(cyclopentadienyl)-1-metalla-3-phosphaindenen ( $\mathrm{M}=$ Titan, Zirkonium)

Stalke, D., Klingebiel, U.,

1457 Lithium- $N$-(fluorsilyl)pentafluoraniline Synthese und Kristallstruktur

\section{Contents (Continued)}

Synthesis of Bis(cyclopentadienyl)-1-metalla-3-phosphaindenes $(\mathrm{M}=$ Titanium, Zirconium)

Lithium $\quad N$-(Fluorosilyl)pentafluoroanilines - Synthesis and Crystal Structure

\section{Organische Chemie/Organic Chemistry}

Hasel, W., Hoffmann, H. M. R. 1461

Hasel, W., Schnick, W., Jansen, M., 1469 Hoffmann, H. M. R.

Aumann, R., Kuckert, E., Krüger, C., Goddard, R., Angermund, $\mathrm{K}$.

Hanack, M., Renz, G., Strähle, J., Schmid, S.

Stamm, Th., Vilsmaier, E. Maas, G., Anders, E.

Molina, P., Alajarin, M., Pérez de Vega, M. J.,

Foces-Foces, M. de la C.,

Cano, F. H.

Hoffmann, R. W., Dresely, S., Lanz, J. W.

Bestmann, H. J., Röder, T., Sühs, K.

Erba, E., Gelmi, M. L., Pocar, D.

Eberhardt, U., Mattern, G., Schiller, G.

Eberhardt, U., Mattern, G.

1531
Regio- und stereoselektive Transformation von 3,3,5,5-Tetramethylcyclohexan-Derivaten. - Oxygenierungen, Ancllierungen und $\mathrm{S}_{\mathrm{v}} 2$ '-Reaktionen

Hochakylierte Cyclohexane. - Röntgenstrukturanalyse, Kraftfeld-Berechnungen und Konformationen von cis/trans-1,4-disubstituierten Cyclohexan-Isomeren

Organische Synthesen mit Übergangsmetallkomplexen, 29. - 2,3-DihydroazetKomplexe und 2-Azitidinone durch Templatsynthese mit Carbenkomplexen, Isocyaniden und Inaminen

(1,2-Naphthalocyaninato)eisen(II)-Verbindungen mit Isocyaniden als axiale Liganden; Kristallstruktur eines Isomeren des Bis(cyclohexylisocyanid)(1,2-naphthalocyaninato)eisen(II)

1487 Herstellung von (Bicycloalkyl)essigsäureDerivaten durch zweifache nucleophile Substitution am Cyclopropan Iminophosphoran-vermittclte Synthese von mesoionischen 1,3,4-Oxadiazolo[3,2-a]-pyridinylium-2-aminiden

Stereoselektive Synthese von Alkoholen, XXVII. - Addition von ( $\alpha$-Chlorcrotyl)boronsäurecstern an Aldehyde

Bororganyle, I. - Überführung von Phosphoniumyliden in Phosphan-Monoalkylboran-Komplexe. - Hydroborierungsreaktionen

5-Oxazolone, IV. - Reaktionen von 5(4H)-Oxazolonen mit Triphenylphosphonium-methyliden

- Über die Bildung zweier ungewöhnlicher mehrkerniger Eisen-Komplexe
Über die stereoselektive Bildung von synund anti-Dicarbonyl(1-methyl- $\eta^{3}-2$-propenyl)nitrosyleisen und die Struktur von synCarbonyl(1-methyl- $\eta^{3}$-2-propenyl)nitrosyl(triphenylphosphan)eisen

- Publikationssprache
Regio- and Stereoselective Transformations of 3,3,5,5-Tetramethylcyclohexane Derivatives. - Oxygenations, Annulations, and $\mathrm{S}_{\mathrm{N}} 2^{\prime}$-Reactions

- Highly Alkylated Cyclohexanes. - X-Ray Crystal Structures, Force-Field Calculations, and Conformations of cis/trans-1,4Disubstituted Cyclohexane Isomers

Organic Syntheses via Transition Metal Complexes, 29. - 2,3-Dihydroazete Complexes and 2-Azetidinones by Template Synthesis with Carbene Complexes, Isocyanides, and Inamines

(1,2-Naphthalocyaninato)iron(II) Compounds with Isocyanides as Axial Ligands; Crystal Structure of an Isomer of Bis(cyclohexylisocyanide)(naphthalocyaninato)iron(II)

Synthesis of (Bicycloalkyl)acetic Acid Derivatives by a Twofold Nucleophilic Substitution at a Cyclopropane

Iminophosphorane-Mediated Synthesis of Mesoionic 1,3,4-Oxadiazolo[3,2-cl]pyridinylium-2-aminides

Stereoselective Synthesis of Alcohols XXVII. - Addition of ( $\alpha$-Chlorocrotyl)boronates to Aldehydes

Organoboron Compounds, I. - Transformation of Phosphonium Ylides into Phosphane Monoalkylborane Complexes. Hydroboration Reactions

5-Oxazolones, IV. - Reactions of 5(4H)Oxazolones with Triphenylphosphonium Methylides

On the Formation of Two Unusual Multinuclear Iron Complexes

On the Stereoselective Formation of synand anti-Dicarbonyl(1-methyl- $\eta^{3}-2$-propenyl)nitrosyliron and the Structure of synCarbonyl(1-methyl- $\eta^{3}-2$-propenyl)nitrosyl(triphenylphosphine)iron

- Language of Publication 


\title{
Highly Alkylated Cyclohexanes. - X-Ray Crystal Structures, Force-Field Calculations, and Conformations of cis/trans-1,4-Disubstituted Cyclohexane Isomers
}

\author{
Winnfried Hasel $^{\text {a,e }}$, Wolfgang Schnick ${ }^{\text {b,c }}$, Martin Jansen ${ }^{\text {b,d }}$, and H. M. R. Hoffmann*a \\ Department of Organic Chemistry, University of Hannover ${ }^{a}$, \\ Schneiderberg 1 B, D-3000 Hannover \\ Department of Inorganic Chemistry, University of Hannover ${ }^{b}$, \\ Callinstr. 9, D-3000 Hannover \\ Present Address: Max-Planck-Institut für Festkörperforschungc, \\ Heisenbergstr. 1, D-7000 Stuttgart 80 \\ Present Address: Institute for Inorganic Chemistry, University of Bonn ${ }^{d}$, \\ Gerhard-Domagk-Straße 1, D-5300 Bonn \\ Present Address: Department of Chemistry, Columbia University ${ }^{\mathrm{e}}$, \\ New York N.Y. 10027
}

Received January 28, 1988

The structures of mesylated cis- and trans-tetramethylshisool cis$\mathbf{2}$ and trans-2 have been elucidated by single-crystal X-ray tẹchniques. In cis-2 the isopropenyl group adopts an axial position in the crystal, and the structural data obtained are in good agreement with those from force-field calculations. In trans-2 the two rotamers arising from rotation of the isopropenyl group were assigned by NOE measurements. Comparison of the spectroscopic data with those of other tetramethyllimonene derivatives showed that these can be classified into compounds with preferred equatorial and preferred axial position of the isopropenyl group.
The chemistry of tetramethyllimonenes (TM-limonenes) has posed interesting configurational and conformational problems, which made it desirable to obtain X-ray crystallographic information. For this purpose we have chosen two

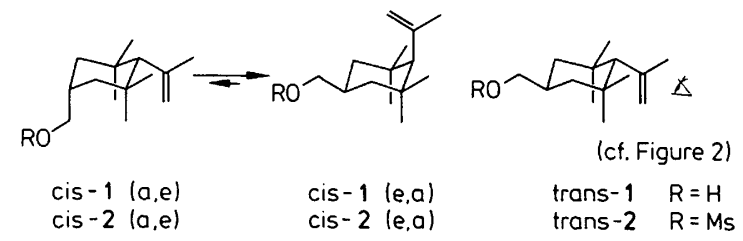

key compounds, i.e. the isomeric TM-shisools trans-1 and cis-1. Although the two alcohols could be prepared stereoselectively, they did not form crystals suitable for X-ray crystallography. We therefore prepared the methanesulfonates trans-2 and cis-2 and have supported the experimental findings by force-field calculations on the alcohols trans-1 and cis-1.

Figure 1 represents the structure of $c i s-2$ in the side view. Figure $2 \mathrm{a}$ shows the side view of trans-2 whereas Figure $2 b$ illustrates the shape of trans-2 from another angle. The
Hochalkylierte Cyclohexane. - Röntgenstrukturanalyse, Kraftfeld-Berechnungen und Konformationen von cis/trans-1,4-disubstituierten Cyclohexan-Isomeren

Die Struktur von mesyliertem cis- und trans-Tetramethylshisool cis-2 und trans-2 wurde durch Einkristall-Röntgenmethoden aufgeklärt. In cis-2 nimmt die Isopropenylgruppe im Kristall eine axiale Stellung ein, und die erhaltenen Strukturdaten stehen in gutem Einklang mit Kraftfeldberechnungen. In trans-2 wurden zwei Rotamere, die durch Rotation der Isopropenylgruppe entstehen, durch NOE-Messungen zugeordnet. Der Vergleich der spektroskopischen Daten mit denen anderer Tetramethyllimonenderivate zeigt, daß diese in Verbindungen mit bevorzugt äquatorialer und bevorzugt axialer Lage der Isopropenylgruppe eingeordnet werden können.

measured and calculated structural data are confronted in Table 1 and are interpreted as follows.

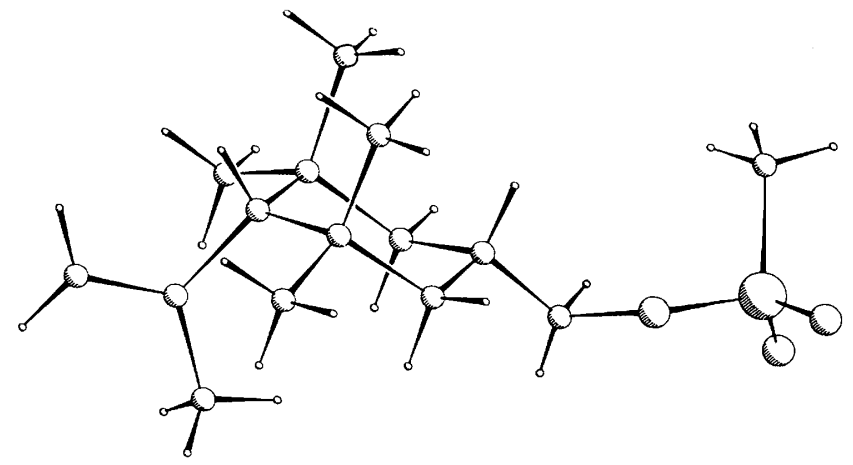

Figure 1. X-ray crystal structure of cis-2

Ring conformation: As suspected previously", the isopropenyl group adopts an axial position in cis-2, whereas in trans-2 it prefers the equatorial position. Apparently, cis-2 $(\mathrm{a}, \mathrm{e})$ is destabilized relative to $\mathrm{cis}-\mathbf{2}(\mathrm{e}, \mathrm{a})$ because it contains an unfavourable interaction of the 1,3,5-syn-triaxial substi- 
tuents and also an unfavourable interaction with the fixed isopropenyl group.

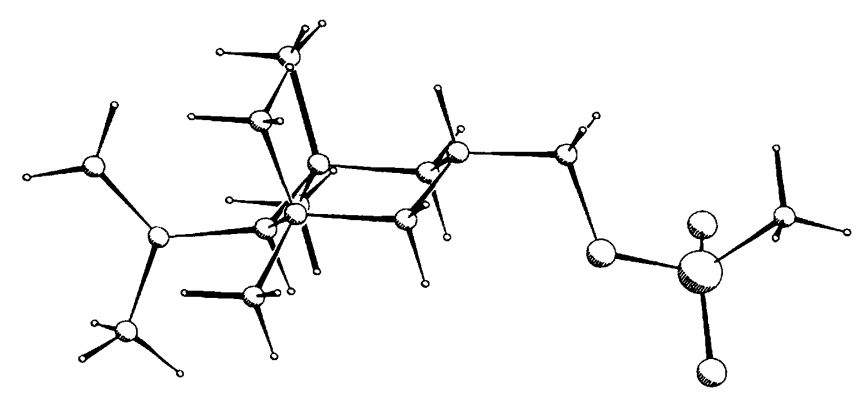

Figure 2a. X-ray crystal structure of trans-2 (side view)

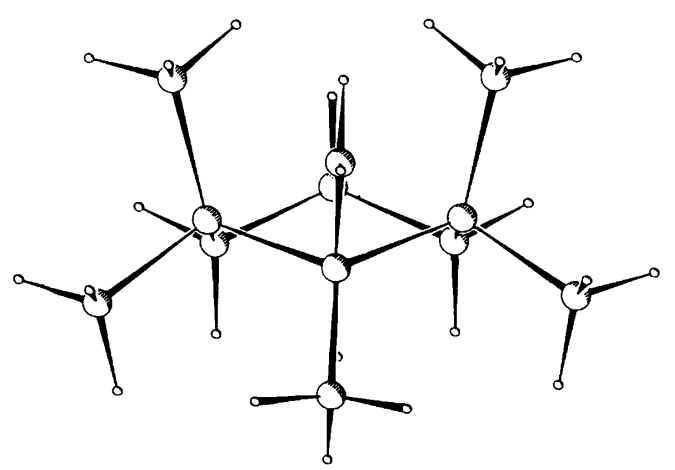

Figure 2b. View on the isopropenyl group in trans-2 along the $C(7)-C(4)$ bond axis [Atoms $C(7)$ and $C(4)$ coincide]

Ring flattening: As shown in Figure $2 \mathrm{~b}$, the syn-axial methyl groups repel each other strongly ${ }^{2}$. Their distance in trans-2 is $3.35 \AA$ compared with a distance of $2.64 \AA$ of the quaternary ring carbons $C(3)$ and $C(5)$. Ring flattening shows up in the structural data, especially those of $c i s-2(e, a)$ (Table 1). The axial isopropenyl group causes a further deformation of the cyclohexane chair. The torsion angles within the ring are clearly smaller than the "ideal angle" of $60^{\circ}$. They are comparatively large near carbon $C(1)$ $(55.5-56.2)$ and small in the vicinity of carbon $\mathrm{C}(4)$ $(44.1-44.5)$. In other words, puckering is most developed at $C(1)$ and least near $C(4)$. Parallel to puckering of the molecule, the internal bond angles are expanded, least at $\mathrm{C}(1)\left(110.7^{\circ}\right)$, but more at the other ring carbons $\left(111.3-114.4^{\circ}\right)$. Furthermore, in cis-2 the normal carboncarbon bond length of $1.534 \AA$ of cyclohexane has increased up to $1.566 \AA$ in the vicinity of the quaternary carbons. The measured structural data of cis-2 suggest that the compound is asymmetrically distorted in the crystal lattice. The measurements showed that two molecules were present in the unit cell, which differed in the position of $\mathrm{CH}_{2} \mathrm{OMs}$. In contrast, the unit cell of trans-2 is smaller ( 820.6 vs. $1691.3 \cdot 10^{6}$ $\mathrm{pm}^{3}$ for cis-2) and the molecule is symmetric within experimental error. The sum of the six internal torsion angles in trans-2 (322.8) is closer to the "ideal value" of $360^{\circ}$ than in cis-2 $\left(301.0^{\circ}\right)$, i.e. trans- $\mathbf{2}$ is flattened less. It is noticeable that the $C(3)-C(4)-C(5)$ bond angle has expanded to $116.0^{\circ}$.

Table 1. Selected experimental (X-ray crystallographic) vs. calculated (force-field) structural parameters of cis-2 and trans-2

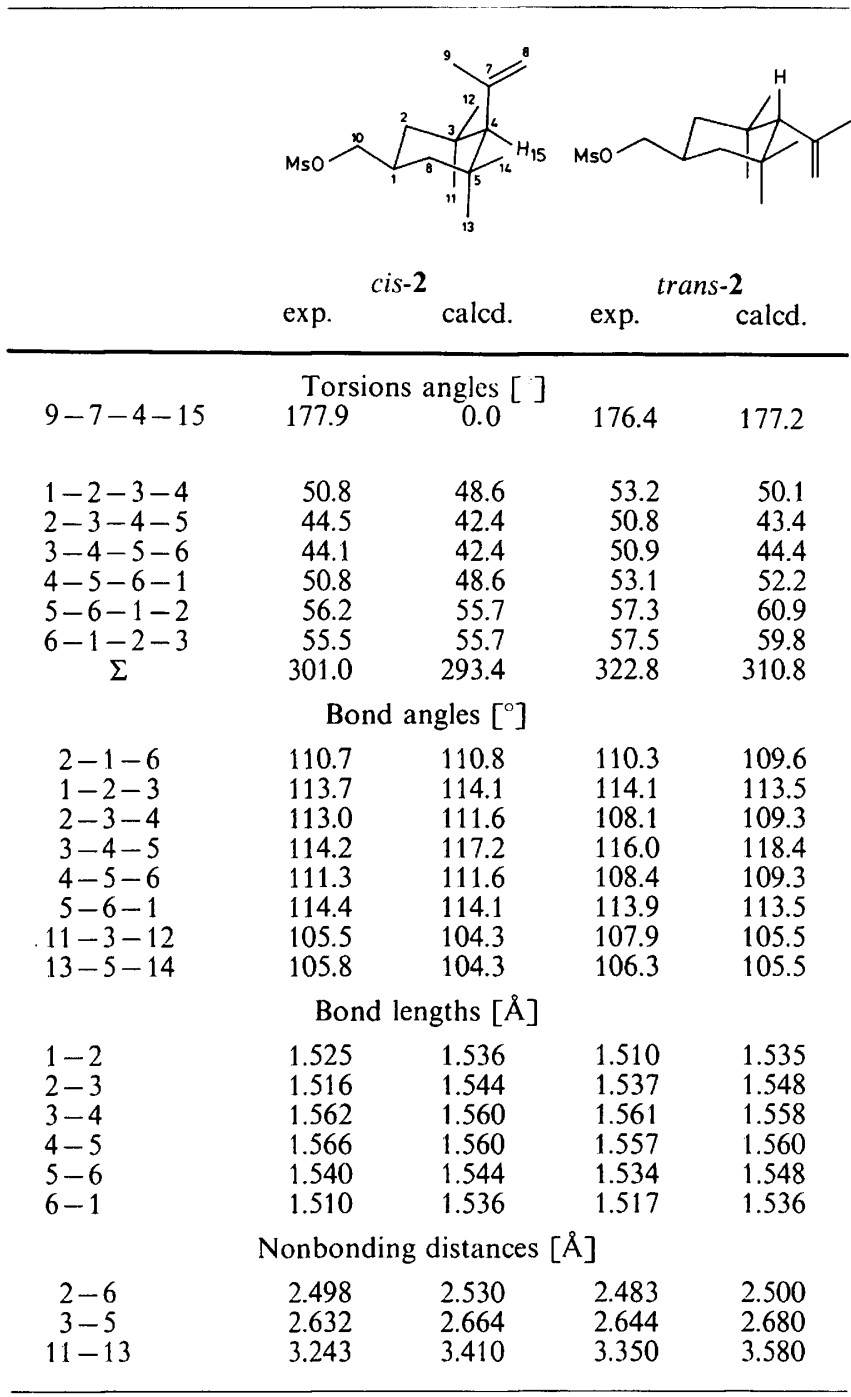

Rotamer population: In the crystal state cis-2 as well as trans- 2 contain one rotamer each, i.e. $\alpha$ - and $\beta$-rotamer, respectively (cf. Table 2 ). In contrast, the force-field calculations suggest that the $\beta$-rotamer is a minimum for both compounds.

Force-field calculations: Table 1 shows satisfactory agreement of measured and calculated structural data. cis-2 (e,a) with axial isopropenyl group is preferred according to the calculations and flattening of cis-2 as well as trans-2 is reproduced in qualitatively correct fashion. Only the extent of flattening is overestimated, and this could be due to an overestimation of nonbonded interactions of $\mathrm{MM} 2^{3)}$.

Spectroscopic determination of the conformation of cis-2 in solution: Crystal structure data and force-field calculations cannot necessarily be extrapolated to the solvated state. It is well-known that axial and equatorial protons clearly differ in their chemical shift. In trans-2 the axial meth- 
ylene protons at $\mathrm{C}(2)$ and $\mathrm{C}(6)$ resonate at $0.98 \mathrm{ppm}$ and the equatorial ones at $1.53 \mathrm{ppm}$. Now in cis-2 and trans-2 the $\mathrm{C}(1)$ proton shows nearly the same chemical shift (2.11 and, respectively, $2.21 \mathrm{ppm}$ ), i. e. it is axial. Hence, cis-2 exists preferentially as cis-2 $(\mathrm{e}, \mathrm{a})$ in solution.

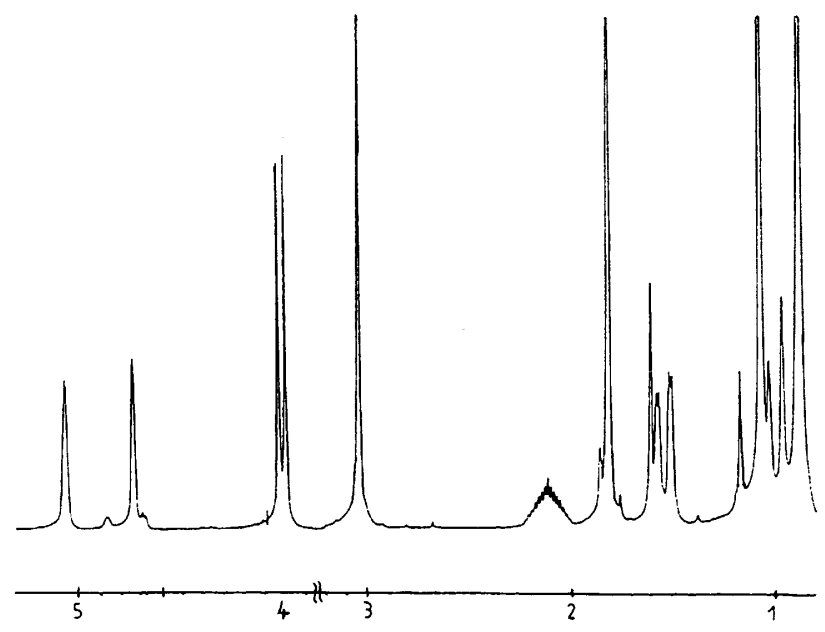

Figure 3. trans-2, $240 \mathrm{~K}$

Table 2. NOE enhancements in trans-2 at $240 \mathrm{~K}$

\begin{tabular}{|c|c|c|c|c|}
\hline \multicolumn{2}{|c|}{$\begin{array}{l}\text { Irradiation at } \\
\delta \quad \text { Proton }\end{array}$} & $\underset{\delta}{\mathrm{NOE}}$ & $(\%)$ & $\begin{array}{l}\text { with } \\
\text { Proton }\end{array}$ \\
\hline 0.87 & $\mathrm{H}-7$ & 1.81 & (1) & H-6 \\
\hline 1.06 & $\mathrm{H}-2$ & $\begin{array}{l}2.12 \\
4.73\end{array}$ & $\begin{array}{l}(2) \\
\text { (1) }\end{array}$ & $\begin{array}{l}\mathrm{H}-1 \\
\mathrm{H}-4\end{array}$ \\
\hline 1.60 & $\mathrm{H}-3$ & $\begin{array}{l}1.81 \\
0.94\end{array}$ & $\begin{array}{r}(5) \\
\cdot(12)\end{array}$ & $\begin{array}{l}\mathrm{H}-6 \\
\mathrm{H}-8\end{array}$ \\
\hline 1.81 & H-6 & $\begin{array}{l}1.60 \\
5.06\end{array}$ & $\begin{array}{l}(1) \\
(1)\end{array}$ & $\begin{array}{l}\mathrm{H}-3 \\
\mathrm{H}-5\end{array}$ \\
\hline 4.73 & H-4 & $\begin{array}{l}1.06 \\
5.06\end{array}$ & $\begin{array}{l}(8) \\
(35)\end{array}$ & $\begin{array}{l}\mathrm{H}-2 \\
\mathrm{H}-5\end{array}$ \\
\hline
\end{tabular}

Hindered rotation of the isopropenyl group of trans-2: The $\mathrm{X}$-ray crystal structure of trans-2, and the MM2 calculations suggest that the $\beta$-rotamer (cf. heading of Table 2 ) is populated preferentially, in contrast to a previous interpretation of solution spectra ${ }^{4)}$. A NOE study of trans-2 at low temperature proved informative. In trans-2 the isopropenyl group is clearly equatorial and all proton signals are wellresolved at $200 \mathrm{MHz}$ (Figure 3). At $240 \mathrm{~K}$ the rotameric equilibrium is frozen and the signals of the olefinic, allylic methyl, and axial methyl protons are split. The preferred rotamer, which according to integration is present to the extent of $89 \%$, showed the enhancements of Table 2. Therefore, a) the $\beta$-rotamer is energetically preferred in the crystal state and also in solution. This finding is at variance with a previous interpretation of the ${ }^{13} \mathrm{C}-\mathrm{NMR}$ spectra ${ }^{4)}$.

b) the assignment of the olefinic protons must be reversed: the proton trans to the methyl group $(\mathrm{H}-4)$ appears at $4.73 \mathrm{ppm}$, the cis proton $\mathrm{H}-5$ at $5.06 \mathrm{ppm}$. Hence, the two rotamers of trans-2 show the chemical shifts in Table 3.

c) contrary to general experience, the axial methyl proton signals appear at lower field than the equatorial ones. This is probably a consequence of van der Waals repulsion and deshielding.

Table 3. Chemical shifts $[\delta, \mathrm{ppm}]$ of olefinic protons in $\alpha$ - und $\beta$-rotamer of trans-2

\begin{tabular}{cccc}
\hline$H(4) \beta$ & $H(4) \alpha$ & $H(5) \beta$ & $H(5) \alpha$ \\
\hline 4.73 & 4.68 & 5.06 & 4.86 \\
\hline
\end{tabular}

Table 4. Chemical shift $[\delta, \mathrm{ppm}]$ of olefinic protons in the $\alpha$ - and $\beta$-rotamer of tetramethyllimonene derivative at low temperature

\begin{tabular}{llllll}
$H(5) \alpha$ \\
\hline
\end{tabular}


Generalization of the spectroscopic measurements in the tetramethyllimonene series. Criteria for distinguishing axial and equatorial isopropenyl groups: As shown above, the isopropenyl group is equatorial in trans-2 (e,e) [and in the derived alcohol trans-1 (e,e)], whereas it is axial in cis-2 (e,a) and in cis-1 (e,a). As it turned out, trans-2, with its characteristic chemical shifts for the $\alpha$ - and $\beta$-rotamer (Table 3), is the prototype of a number of TML derivatives (Table 4) which show similar spectroscopic behaviour at low temperature, when the rotameric equilibrium is "frozen" on the NMR time scale: in 3-7 the isopropenyl group prefers the equatorial position. In 4,5 , and 6 the six-membered ring is saturated as in $\mathbf{8}$ and $\mathbf{9}$. However, 8 and $\mathbf{9}$ behave spectroscopically like cis-1, i.e. the isopropenyl group is axial. Apparently, ring inversion in $\mathbf{8}$ and $\mathbf{9}$ does not pay energetically, because of the build-up of the syn-triaxial interaction. On the other hand, in $\mathbf{4 , 5}$, and $\mathbf{6}$ a $s y n$-triaxial interaction of substituents is present, irrespective of the position of the isopropenyl group.

Conclusions: Although the isopropenyl group is large, it cannot automatically be assumed to adopt the equatorial position. In the cis-1,4-disubstituted series cis-1, 8, and $\mathbf{9}$ an equatorial isopropenyl group would cause an unfavourable syn-triaxial interaction of substituents. Instead, the isopropenyl group adopts the axial position.

We thank Dr. E. Hofer for the NOE measurements and the Fonds der Chemischen Industrie for financial support.

\section{Experimental}

trans-2: A solution of trans-TM-shisool (trans-1) $)^{\mathrm{t}}(0.32 \mathrm{~g}, 1.52$ $\mathrm{mmol})$ and DMAP (10 $\mathrm{mg}, 0.08 \mathrm{mmol})$ in absol. pyridine $(3 \mathrm{ml})$ was cooled to 0 to $-10 \mathrm{C}$, and methanesulfonyl chloride $(0.22 \mathrm{~g}, 1.69$ $\mathrm{mmol}$ ) in $1 \mathrm{ml}$ of pyridine was stirred in slowly. The mixture was stirred for $4 \mathrm{~h}$ at 0 to $-10^{\circ} \mathrm{C}$, then ice/water $(5 \mathrm{ml})$ was dropped in, and the aqueous phase was extracted with ether $(2 \times)$. The combined ether phase was washed with ice-cold $10 \%$ aqueous $\mathrm{HCl}(2 \mathrm{x})$, aqueous $\mathrm{NaHCO}_{3}$ and $\mathrm{NaCl}$, and dried $\left(\mathrm{Na}_{2} \mathrm{SO}_{4}\right)$. After removal of the solvent, the resulting yellow crystals were recrystallized from light petroleum to afford trans-2; colourless needles, $0.33 \mathrm{~g} \mathrm{(75 \% ),}$ mp $101-103$ C. $-200-\mathrm{MHz}^{ } \mathrm{H}-\mathrm{NMR}\left(\mathrm{CDCl}_{3}\right): \delta=0.88(\mathrm{~s}, 6 \mathrm{H}$, eq $\left.\mathrm{CH}_{3}\right), 0.98\left(\mathrm{~d}, 2 \mathrm{H}\right.$, ax $\left.\mathrm{CH}_{2}\right), 1.08\left(\mathrm{~s}, 6 \mathrm{H}\right.$, ax $\left.\mathrm{CH}_{3}\right), 1.45-1.58(\mathrm{~m}$, $2 \mathrm{H}$, eq $\left.\mathrm{CH}_{2}\right), 1.6(\mathrm{~m}, 1 \mathrm{H}$, allyl $\mathrm{CH}), 2.0-2.33\left(\mathrm{~m}, 1 \mathrm{H}, \mathrm{CHCH}_{2} \mathrm{O}\right)$, $3.02\left(\mathrm{~s}, 3 \mathrm{H}, \mathrm{SO}_{2} \mathrm{CH}_{3}\right), 4.02$ (d, $\left.J=6 \mathrm{~Hz}, 2 \mathrm{H}, \mathrm{CH}_{2} \mathrm{OMs}\right), 4.73$ (s, $1 \mathrm{H}$, trans $\left.-\mathrm{CH}_{2}=\mathrm{CCH}_{3}\right), 5.03\left(\mathrm{~s}, 1 \mathrm{H}\right.$, cis $\left.-\mathrm{CH}_{2}=\mathrm{CCH}_{3}\right)$.

cis-2: cis-TM-shisool (cis-1) $(0.96 \mathrm{~g}, 4.57 \mathrm{mmol})$ and DMAP (34 mg, $0.27 \mathrm{mmol}$ ) in $10 \mathrm{ml}$ of pyridine was allowed to react with methanesulfonyl chloride $(0.65 \mathrm{~g}, 5 \mathrm{mmol})$ in $2.5 \mathrm{ml}$ of pyridine, giving cis-2 $(1.1 \mathrm{~g} 84 \%)$ mp $53-54 \mathrm{C}$ - $200-\mathrm{MHz}{ }^{1} \mathrm{H}-\mathrm{NMR}$ $\left(\mathrm{CDCl}_{3}\right)$ (because of hindered rotation, the signals are partially split and broadened considerably): $\delta=0.91+0.96\left(\mathrm{~s}, 6 \mathrm{H}, 2 \mathrm{CH}_{3}\right), 1.15$ $\left(\mathrm{s}, 6 \mathrm{H}, 2 \mathrm{CH}_{3}\right), 1.26-1.51\left(\mathrm{~m}, 4 \mathrm{H}, 2 \mathrm{CH}_{2}\right), 1.77+1.91(\mathrm{~m}, 4 \mathrm{H}$, allyl $\mathrm{CH}_{3}+$ allyl $\left.\mathrm{CH}\right), 2.07-2.24\left(\mathrm{~m}, 1 \mathrm{H}, \mathrm{CHCH} \mathrm{CHM}_{2} \mathrm{OM}, 3.02(\mathrm{~s}, 3 \mathrm{H}\right.$, $\mathrm{SO}_{2} \mathrm{CH}_{3}$ ), 4.07 (d, $\left.J=6 \mathrm{~Hz}, 2 \mathrm{H}, \mathrm{CH}_{2} \mathrm{OMs}\right), 4.55-4.95(\mathrm{~m}, 2 \mathrm{H}$, olefin $\mathrm{H}$ ).

The intensitics were measured in the $\omega$-scan mode on a SiemensStoe-AED-2-Diffractometer with Mo- $K_{\alpha}$ radiation (graphite monochromator) and corrected as usual. The structure was determined by direct methods (MULTAN-80) and refined using the program system STRLICSY (STOE). The hydrogen atoms were refined iso-
Table 5. X-ray crystal data

\begin{tabular}{lll}
\hline & cis-2 & trans-2 \\
\hline Recrystallized from & ether/light petroleum, $1: 1$ \\
Empirical formula & $\mathrm{C}_{15} \mathrm{H}_{28} \mathrm{SO}_{3}$ & $\mathrm{C}_{15} \mathrm{H}_{28} \mathrm{SO}_{3}$ \\
Molecular mass & 288.5 & 288.5 \\
$Z$ & 4 & 2 \\
Space group & $P \overline{1}$ & $P \overline{1}$ \\
$a[\mathrm{pm}]$ & $776.0(25)$ & $638.4(28)$ \\
$b[\mathrm{pm}]$ & $1283.8(55)$ & $782.5(28)$ \\
$c[\mathrm{pm}]$ & $1845.0(108)$ & $1739.3(67)$ \\
$\alpha\left[^{\circ}\right]$ & $109.8(3)$ & $95.0(3)$ \\
$\beta\left[{ }^{\circ}\right]$ & $100.2(4)$ & $96.6(4)$ \\
$\gamma\left[{ }^{\circ}\right]$ & $92.5(3)$ & $106.6(3)$ \\
$V\left[\mathrm{pm}{ }^{3} \cdot 10^{6}\right]$ & 1691.3 & 820.6 \\
Number of centered reflexions & 38 & 26 \\
Diffractometer & $\mathrm{AED}-2-\mathrm{Siemens}-\mathrm{Stoe}$ \\
Temperature [ C] & 21 & 21 \\
Radiation used & $\mathrm{Mo}-K_{\alpha} ; \lambda=71.069 \mathrm{pm} ;$ \\
& graphite monochromator \\
Calculated density $D_{\mathrm{x}}\left[\mathrm{g} / \mathrm{cm}^{3}\right]$ & 1.133 & 1.168 \\
Scan mode & $2.4 ; \omega$ & 3.3 \\
$2 \Theta$-range $\left[{ }^{\circ}\right]$ & $2 \leqq 2 \Theta \leqq 55$ & $2 \leqq 2 \Theta \leqq 55$ \\
Number of reflexions measured & 7963 & 4875 \\
Number of observed reflexions & 3810 & 3083 \\
$\left(F_{\mathrm{o}} \geqq 3 \sigma\left(F_{\mathrm{o}}\right)\right)$ & & \\
Number of variables & 344 & 172 \\
$R$ & 0.0940 & 0.0651 \\
$R_{\mathrm{w}}, w=1 / \sigma^{2}\left(F_{\mathrm{o}}\right)$ & 0.0818 & 0.0549 \\
\hline
\end{tabular}

Table 6. Local $\left(\times 10^{4}\right)$ and thermal parametcrs ${ }^{i \prime}\left[\mathrm{pm}^{2}\right]$ of cis-2

\begin{tabular}{|c|c|c|c|c|}
\hline $\begin{array}{l}\text { Alom } \\
\text { S1 }\end{array}$ & $\begin{array}{r}x / a \\
478(2)\end{array}$ & $\begin{array}{r}y / b \\
5785(1)\end{array}$ & $\begin{array}{r}2 / c \\
1393(1)\end{array}$ & $\begin{array}{l}U_{\mathrm{eq}} \\
601\end{array}$ \\
\hline 01 & $-966(6)$ & $5064(3)$ & $854(2)$ & 844 \\
\hline 02 & $2052(6)$ & $5338(3)$ & $1593(3)$ & 959 \\
\hline 03 & $63(5)$ & $6393(3)$ & $2193(2)$ & 693 \\
\hline $\mathrm{C} 1$ & $964(7)$ & $6837(4)$ & $1061(3)$ & 737 \\
\hline $\mathrm{H} 1 \mathrm{a}$ & $1945(7)$ & $7337(4)$ & $1420(3)$ & 811 \\
\hline $\mathrm{H} 1 \mathrm{~b}$ & $1254(7)$ & $6521(4)$ & $552(3)$ & 811 \\
\hline $\mathrm{H} 1 \mathrm{C}$ & $.45\langle 7\rangle$ & $7237(4)$ & $1022(3)$ & 811 \\
\hline $\mathrm{C} 2$ & $.1906(7)$ & $6597(5)$ & $2194(3)$ & 692 \\
\hline $\mathrm{H} 2 \mathrm{a}$ & $-2630(7)$ & $5896(5)$ & $2006(3)$ & 762 \\
\hline $\mathrm{H} 2 \mathrm{~b}$ & $.2288(7)$ & $7017(5)$ & $1864(3)$ & 762 \\
\hline C3 & $.2062(6)$ & $7219(4)$ & $3033(3)$ & 486 \\
\hline $\mathrm{H} 3 \mathrm{a}$ & $.1282(6)$ & $7899(4)$ & $3241(3)$ & 534 \\
\hline $\mathrm{C} 4$ & $.3973(6)$ & $7455(4)$ & $3029(3)$ & 550 \\
\hline $\mathrm{H} 4 \mathrm{a}$ & $-4688(6)$ & $6749(4)$ & $2821(3)$ & 605 \\
\hline $\mathrm{H} 4 \mathrm{~b}$ & $.4300(6)$ & $7878(4)$ & $2695(3)$ & 605 \\
\hline C5 & $.4329(6)$ & $8063(4)$ & $3841(3)$ & 538 \\
\hline $\mathrm{C} 6$ & $-3615(6)$ & $7506(4)$ & $4454(3)$ & 563 \\
\hline $\mathrm{H} 6 \mathrm{a}$ & $-3471(6)$ & $8098(4)$ & $4953(3)$ & 620 \\
\hline $\mathrm{C7}$ & $-1712(7)$ & $7156(5)$ & $4426(3)$ & 592 \\
\hline $\mathrm{C8}$ & $-1490(7)$ & $6582(4)$ & $3572(3)$ & 584 \\
\hline $\mathrm{H} 8 \mathrm{a}$ & $-2194(7)$ & $5872(4)$ & $3361(3)$ & 642 \\
\hline $\mathrm{H} 8 \mathrm{~b}$ & $-273(7)$ & $6472(4)$ & $3578(3)$ & 642 \\
\hline $\mathrm{Cg}$ & $.3527(8)$ & $9283(4)$ & $4127(4)$ & 806 \\
\hline $\mathrm{H} 9 \mathrm{a}$ & $.3745(8)$ & $9671(4)$ & $4642(4)$ & 887 \\
\hline $\mathrm{H} 9 \mathrm{~b}$ & $.2280(8)$ & $9315(4)$ & $4149(4)$ & 887 \\
\hline $\mathrm{H} 9 \mathrm{C}$ & $.4060(8)$ & $9627(4)$ & $3768(4)$ & 887 \\
\hline$C_{10}$ & $.6335(7)$ & $8104(5)$ & $3770(4)$ & 786 \\
\hline $\mathrm{H} 10 \mathrm{a}$ & $.6898(7)$ & $7355(5)$ & $3593(4)$ & 864 \\
\hline $\mathrm{H} 10 \mathrm{~b}$ & $.6593(7)$ & $8521(5)$ & $4271(4)$ & 864 \\
\hline
\end{tabular}


Table 6 (Continued)

\begin{tabular}{|c|c|c|c|c|}
\hline $\mathrm{H} 10 \mathrm{c}$ & $.6765(7)$ & $8448(5)$ & $3395(4)$ & 864 \\
\hline$C 11$ & - $286(7)$ & $8165(5)$ & $4836(3)$ & 833 \\
\hline H11a & $-436(7)$ & $8530\langle 5\rangle$ & $5366(3)$ & 917 \\
\hline $\mathrm{H} 11 \mathrm{~b}$ & $870(7)$ & $7926(5)$ & $4845(3)$ & 917 \\
\hline $\mathrm{H} 11 \mathrm{c}$ & $-423(7)$ & $8674(5)$ & $4556(3)$ & 917 \\
\hline $\mathrm{C} 12$ & $.1306(8)$ & $6343(6)$ & $4861(4)$ & 1017 \\
\hline $\mathrm{H} 12 \mathrm{a}$ & $-1434(8)$ & $6692(6)$ & $5396(4)$ & 1119 \\
\hline $\mathrm{H} 12 \mathrm{~b}$ & $.2120(8)$ & $5679(6)$ & $4612(4)$ & 1119 \\
\hline $\mathrm{H} 12 \mathrm{c}$ & $-124(9)$ & $6153(6)$ & $4855(4)$ & 1119 \\
\hline $\mathrm{C} 13$ & $-4892(8)$ & $6621(6)$ & $4485(4)$ & 739 \\
\hline C14 & $-5484(9)$ & $5581(5)$ & $3797(5)$ & 1058 \\
\hline $\mathrm{H} 14 \mathrm{a}$ & $-4907(9)$ & $5608\langle 5\rangle$ & $3383(5)$ & 1163 \\
\hline$H 14 b$ & $-5171(9)$ & $4952(5)$ & $3941(5)$ & 1163 \\
\hline $\mathrm{H} 14 \mathrm{C}$ & $-6737(9)$ & $5511(5)$ & $3617(5)$ & 1163 \\
\hline C15 & $-5546(9)$ & $6771(7)$ & $5137(4)$ & 1077 \\
\hline $\mathrm{H} 15 \mathrm{a}$ & $-5157(9)$ & $7451(7)$ & $5576(4)$ & 1185 \\
\hline $\mathrm{H} 15 \mathrm{~b}$ & $.6370(9)$ & $6220(7)$ & $5173(4)$ & 1185 \\
\hline S2 & $5772(3)$ & $7394(2)$ & $143(1)$ & 823 \\
\hline C16 & $5430(10)$ & $6094(6)$ & $-549(6)$ & 1537 \\
\hline $\mathrm{H} 16 \mathrm{a}$ & $5824\{10\}$ & $6106(6)$ & $-1011(6)$ & 1691 \\
\hline $\mathrm{H} 16 \mathrm{~b}$ & $6086(10)$ & $5609(6)$ & $.336(6)$ & 1691 \\
\hline $\mathrm{H} 16 \mathrm{c}$ & $4199(10)$ & $5826(6)$ & $.684(6)$ & 1691 \\
\hline O4 & $7483(7)$ & $7898(4)$ & $228(3)$ & 1164 \\
\hline$\infty$ & $5214(7)$ & $7382(6)$ & $797(3)$ & 1543 \\
\hline O6 & $4701(\cdot)$ & $8054(\cdot)$ & $-289(-)$ & 1813 \\
\hline C17 & $2911(-)$ & $8070(\cdot)$ & $.419(-)$ & 2381 \\
\hline $\mathrm{H} 17 \mathrm{a}$ & $2602(-)$ & $8740(-)$ & $-62(-)$ & 2619 \\
\hline $\mathrm{H} 17 \mathrm{~b}$ & $2344(-)$ & $7435(-)$ & $-356(-)$ & 2619 \\
\hline $\mathrm{C} 18$ & $2388(12)$ & $8025(7)$ & $-1265(4)$ & 1069 \\
\hline H18a & $2867(12)$ & $7402(7)$ & $-1593(4)$ & 1175 \\
\hline C19 & $449(12)$ & $7690(6)$ & $.1361(4)$ & 1007 \\
\hline $\mathrm{H} 19 \mathrm{a}$ & $309(12)$ & $7023(6)$ & $-1242(4)$ & 1108 \\
\hline $\mathrm{H} 19 \mathrm{~b}$ & $.9(12)$ & $8282(6)$ & $.994(4)$ & 1108 \\
\hline $\mathrm{C} 20$ & $-632(8)$ & $7483(5)$ & $-2177(4)$ & 703 \\
\hline $\mathrm{C} 21$ & $-313(6)$ & $8491(4)$ & $.2437(3)$ & 523 \\
\hline $\mathrm{H} 21 \mathrm{a}$ & $-636(6)$ & $8189(4)$ & $-3001(3)$ & 575 \\
\hline $\mathrm{C} 22$ & $1664(7)$ & $8965(5)$ & $-2286(3)$ & 593 \\
\hline $\mathrm{C} 23$ & $2641(7)$ & $9051(6)$ & $-1469(4)$ & 832 \\
\hline $\mathrm{H} 23 \mathrm{a}$ & $3876(7)$ & $9231(6)$ & $-1430(4)$ & 915 \\
\hline $\mathrm{H} 23 \mathrm{~b}$ & $2214(7)$ & $9644(6)$ & $-1090\langle 4\rangle$ & 915 \\
\hline $\mathrm{C} 24$ & $1768(8)$ & $10129(5)$ & $-2362(4)$ & 984 \\
\hline $\mathrm{H} 24 \mathrm{a}$ & $1164(8)$ & $10080(5)$ & $\cdot 2876(4)$ & 1082 \\
\hline $\mathrm{H} 24 \mathrm{~b}$ & $1235(8)$ & $10630(5)$ & $.1970(4)$ & 1082 \\
\hline $\mathrm{H} 24 \mathrm{C}$ & $2984(8)$ & $10401(5)$ & $-2283(4)$ & 1082 \\
\hline C25 & $2614(8)$ & $8228(5)$ & $-2910(4)$ & 846 \\
\hline $\mathrm{H} 25 \mathrm{a}$ & $1997(8)$ & $8172(5)$ & $-3423(4)$ & 931 \\
\hline $\mathrm{H} 25 \mathrm{~b}$ & $3809(8)$ & $8543(5)$ & $-2826(4)$ & 931 \\
\hline $\mathrm{H} 25 \mathrm{C}$ & $2605(8)$ & $7500(5)$ & $-2873(4)$ & 931 \\
\hline $\mathrm{C} 26$ & $-2605(9)$ & $7269(5)$ & $.2167(5)$ & 1138 \\
\hline $\mathrm{H} 26 \mathrm{a}$ & $-3301(9)$ & $7135(5)$ & $-2681(5)$ & 1252 \\
\hline $\mathrm{H} 26 \mathrm{~b}$ & $-2806(9)$ & $6637(5)$ & $-2014(5)$ & 1252 \\
\hline $\mathrm{H} 26 \mathrm{c}$ & $-2932(9)$ & $7919(5)$ & $-1796(5)$ & 1252 \\
\hline $\mathrm{C} 27$ & $-132(9)$ & $6395(5)$ & $-2759(4)$ & 983 \\
\hline $\mathrm{H} 27 \mathrm{a}$ & $-799(9)$ & $6272(5)$ & $-3277(4)$ & 1081 \\
\hline $\mathrm{H} 27 \mathrm{~b}$ & $1103(9)$ & $6479(5)$ & $-2759(4)$ & 1081 \\
\hline $\mathrm{H} 27 \mathrm{c}$ & $.397(9)$ & $5771(5)$ & $-2608(4)$ & 1081 \\
\hline $\mathrm{C} 28$ & $-1506(7)$ & $9389(5)$ & $-2162(4)$ & 664 \\
\hline C29 & $-1415(8)$ & $10022(5)$ & $.1318(4)$ & 919 \\
\hline
\end{tabular}

Table 6 (Continued)

\begin{tabular}{lrrrr}
\hline H29a & $-529(8)$ & $9756(5)$ & $-1012(4)$ & 1010 \\
H29b & $-1110(8)$ & $10800(5)$ & $-1210(4)$ & 1010 \\
H29c & $-2533(8)$ & $9916(5)$ & $-1183(4)$ & 1010 \\
C30 & $-2666(9)$ & $9613(6)$ & $-2705(5)$ & 1079 \\
H30a & $-2710(9)$ & $9193(6)$ & $-3250(5)$ & 1187 \\
H30b & $-3438(9)$ & $10180(6)$ & $-2561(5)$ & 1187 \\
\hline
\end{tabular}

a) $U_{\mathrm{eq}}$ is calculated from the orthogonal $U_{i j}$-tensor $\exp \left[2 \pi^{2}\left(h^{2} a^{* 2}\right.\right.$ $\left.\left.U_{11}+k^{2} b^{* 2} U_{22}+\ldots 2 h k a^{*} b^{*} U_{12} \ldots\right)\right]$.

Table 7. Local $\left(\times 10^{4}\right)$ and thermal parameters ${ }^{\mathrm{a})}\left[\mathrm{pm}^{2}\right]$ of trans-2

\begin{tabular}{|c|c|c|c|c|}
\hline Alom & $x / a$ & $y / b$ & $z / c$ & $u_{e q}$ \\
\hline S1 & $8836(1)$ & $6985(1)$ & 510 & 466 \\
\hline C1 & $7991(4)$ & $7010(4)$ & $-473(1)$ & 583 \\
\hline $\mathrm{H} 1 \mathrm{a}$ & $6421(4)$ & $6802(4)$ & $.564(1)$ & 641 \\
\hline H1b & $8721(4)$ & $8758(4)$ & $-624(1)$ & 641 \\
\hline $\mathrm{H} 1 \mathrm{c}$ & $8363(4)$ & $6083(4)$ & $.776(1)$ & 641 \\
\hline 01 & $11138(3)$ & $7293(3)$ & $647(1)$ & 942 \\
\hline $\mathrm{O} 2$ & $7422(3)$ & $5434(3)$ & $750(1)$ & 684 \\
\hline$\infty$ & $8490(2)$ & $8715(2)$ & $926(1)$ & 493 \\
\hline $\mathrm{C} 2$ & $6246(4)$ & $8846(4)$ & $894(1)$ & 521 \\
\hline $\mathrm{H} 2 \mathrm{a}$ & $5214(4)$ & $7661(4)$ & $801(1)$ & 573 \\
\hline $\mathrm{H} 2 \mathrm{~b}$ & $5957(4)$ & $9518(4)$ & $479(1)$ & 573 \\
\hline $\mathrm{C} 3$ & $6005(4)$ & $9777(3)$ & $1662(1)$ & 411 \\
\hline $\mathrm{H} 3 \mathrm{a}$ & $4588(4)$ & $9983(3)$ & $1587(1)$ & 452 \\
\hline $\mathrm{C} 4$ & $6023(4)$ & $8635(3)$ & $2319(1)$ & 488 \\
\hline $\mathrm{H} 4 \mathrm{a}$ & $4912(4)$ & $7497(3)$ & $2166(1)$ & 537 \\
\hline $\mathrm{H} 4 \mathrm{~b}$ & $7451(4)$ & $8450(3)$ & $2403(1)$ & 537 \\
\hline $\mathrm{C} 5$ & $5615(4)$ & $9486(3)$ & $3096(2)$ & 503 \\
\hline $\mathrm{C} 6$ & $7301(4)$ & $11406(3)$ & $3296(1)$ & 392 \\
\hline $\mathrm{H} 6 \mathrm{a}$ & $8701(4)$ & $11169(3)$ & $3326(1)$ & 431 \\
\hline $\mathrm{C} 8$ & $7723(4)$ & $11599(3)$ & $1889(1)$ & 426 \\
\hline $\mathrm{H} 8 \mathrm{a}$ & $7669(4)$ & $12311(3)$ & $1468(1)$ & 468 \\
\hline $\mathrm{H} 8 \mathrm{~b}$ & $9145(4)$ & $11401(3)$ & $1970(1)$ & 468 \\
\hline $\mathrm{C} 9$ & $3156(4)$ & $9399(4)$ & $3051(2)$ & 781 \\
\hline $\mathrm{H} 9 \mathrm{a}$ & $2923(4)$ & $9947(4)$ & $3536(2)$ & 860 \\
\hline $\mathrm{H} 9 \mathrm{~b}$ & $2778(4)$ & $10039(4)$ & $2636(2)$ & 860 \\
\hline $\mathrm{H} 9 \mathrm{c}$ & $2242(4)$ & $8171(4)$ & $2954(2)$ & 860 \\
\hline $\mathrm{C} 13$ & $7311(4)$ & $12326(3)$ & $4105(1)$ & 520 \\
\hline $\mathrm{C7}$ & $7428(4)$ & $12640(3)$ & $2637(1)$ & 390 \\
\hline $\mathrm{C} 10$ & $6126(7)$ & $8354(4)$ & $3730(2)$ & 910 \\
\hline $\mathrm{H} 10 \mathrm{a}$ & $5874(7)$ & $8848(4)$ & $4224(2)$ & 1001 \\
\hline $\mathrm{H} 1 \mathrm{Ob}$ & $5202(7)$ & $7132(4)$ & $3605(2)$ & 1001 \\
\hline $\mathrm{H} 10 \mathrm{C}$ & $7648(7)$ & $8388(4)$ & $3759(2)$ & 1001 \\
\hline C11 & $9479(5)$ & $14274(3)$ & $2864(2)$ & 652 \\
\hline H11a & $10743(5)$ & $13858(3)$ & $2978(2)$ & 717 \\
\hline H11b & $9676(5)$ & $14983(3)$ & $2439(2)$ & 717 \\
\hline $\mathrm{H} 11 \mathrm{C}$ & $9318(5)$ & $14995(3)$ & $3316(2)$ & 717 \\
\hline$C_{12}$ & $5476(4)$ & $13380(3)$ & $2461(2)$ & 559 \\
\hline $\mathrm{H} 12 \mathrm{a}$ & $5275(4)$ & $14028(3)$ & $2927(2)$ & 615 \\
\hline $\mathrm{H} 12 \mathrm{~b}$ & $5758(4)$ & $14172(3)$ & $2068(2)$ & 615 \\
\hline $\mathrm{H} 12 \mathrm{C}$ & $4164(4)$ & $12400(3)$ & $2276(2)$ & 615 \\
\hline C14 & $5712(5)$ & $12981\langle 4\rangle$ & $4316(2)$ & 715 \\
\hline $\mathrm{H} 14 \mathrm{a}$ & $4438(5)$ & $12881(4)$ & $3944(2)$ & 787 \\
\hline $\mathrm{H} 14 \mathrm{~b}$ & $5841(5)$ & $13558(4)$ & $4837(2)$ & 787 \\
\hline C15 & $9273(6)$ & $12487(5)$ & $4680(2)$ & 926 \\
\hline $\mathrm{H} 15 \mathrm{a}$ & $10246(6)$ & $11946(5)$ & $4438(2)$ & 1019 \\
\hline $\mathrm{H} 15 \mathrm{~b}$ & $10029(6)$ & $13732(5)$ & $4856(2)$ & 1019 \\
\hline $\mathrm{H} 15 \mathrm{c}$ & $8820(6)$ & $11880(5)$ & $5117(2)$ & 1019 \\
\hline
\end{tabular}

a) $U_{\text {eq }}$ is calculated from the orthogonal $U_{i j}$-tensor $\exp \left[2 \pi^{2}\left(h^{2} a^{* 2}\right.\right.$ $\left.\left.U_{11}+k^{2} b^{* 2} U_{22}+\ldots 2 h k a^{*} b^{*} U_{12} \ldots\right)\right]$.

tropically, all other atoms anisotropically. All parameters were finally refined with the weighting $w=1 / \sigma^{2}\left(F_{\mathrm{o}}\right)^{5}$.

Force-field calculations were performed with the MM2 program $^{4)}$. 


\section{CAS Registry Numbers}

trans-1: 113831-04-2 / cis-1: 113831-05-3 / trans-2: 113831-06-4/ cis-2: 113831-()7-5 / 3: 68930-33-6 / 4: 84602-70-0 / 5: 83379-14-0/ 6: 83379-15-1 / 7: 96043-26-4 / 8: 113831-08-6 / 9: 113831-09-7

1) W. Hasel, H. M. R. Hoffmann, Chem. Ber. 121 (1988) 1461; preceding paper.

2) The consequence of syn-axial repulsion ("reflex effect") has also been studied in 2,2,6,6-tetramethylcyclohexanes. For selected references cf. H. J. Schneider, W. Freitag, Chem. Ber. 112 (1979)
16. - B. Waegell, G. Ourisson, Bull. Soc. Chim. Gr. 1963, 495 , 496, 503. - C. W. Jefford, A. Baretta, J. Fournier, B. Waegell, Helv. Chim. Acta 53 (1970) 1180.

${ }^{3)}$ U. Burkert, N. L. Allinger, in Molecular Dynamics, ACS Monograph No. 177, Am. Chem. Soc., 1982.

${ }^{4)}$ H. M. R. Hoffmann, R. J. Giguere, D. Pauluth, E. Hofer, J. Org. Chem. 48 (1983) 1155.

5) Further details concerning the X-ray analysis may be obtained from Fachinformationszentrum Energie, Physik, Mathematik GmbH, D-7514 Eggenstein-Leopoldshafen 2, by specifying registry number CSD-52986, authors, and the reference to this publication.

[18/88] 